\title{
Consumer Preference for Local Apples Malang and Imported Apples during the Pandemic
}

\author{
Riyanti Isaskar ${ }^{1, *}$, Hani Perwitasari ${ }^{2}$ \\ ${ }^{1}$ Dept. Agricultural Socio-Economics, Faculty of Agriculture, Brawijaya University, Malang, \\ Indonesia \\ ${ }^{2}$ Dept. Agricultural Socio-Economics, Faculty of Agriculture, Gadjah Mada University, Yogyakarta, \\ Indonesia
}

\begin{abstract}
Indonesian people tend to view imported fruit as a more prestigious value compared to local fruit. The case of pandemic covid19 has an impact on the imported fruit market in every country, especially apples that are famous in the Indonesian domestic market, among others, coming from China. People's fear of the transmission of covid19 brings its perception for consumers in consuming fruit originating from China. The purpose of this study is to know consumer preferences towards local Malang apples and imported apples, as well as identify the factors that make up those consumer preferences. The method used is a quantitative method of description using Principle Component Analysis (PCA). The result is that consumer preferences are influenced by the price, favorite, and place of purchase of apples. While the factors that shape consumer preferences in the consumption of local apples obtained formed three factors: performance, appearance and green product and imported apples obtained three factors are performance, packaging and green product that has similarity to the description are only slightly different from the attributes formed in it.
\end{abstract}

\section{Introduction}

Consumption patterns of society, in general, prefer to consume basic needs first compared to other needs, but at the time of this pandemic, all changed. In the study [1], it is known that the consumption patterns of the community during this pandemic have changed, namely consumption patterns in healthy food that can be useful to increase immunity has increased. The change in consumption patterns is because the government urges each of its people to improve health, especially maintaining personal hygiene and consuming nutritious food, and social distancing. The fulfillment of healthy food is to consume a lot of fruits and vegetables. Therefore, the Covid-19 pandemic will have an impact on increasing demand for fruits and vegetables, as well as the demand for both local and imported fruits. Various imported fruits flood the domestic market at prices that are quite competitive with local fruit [7]. Apple import data in 2015-2019 tends to increase every year from

\footnotetext{
* Corresponding author: riyantiisaskar@gmail.com
} 
US\$118,081.4 million or around IDR 1,751 trillion in 2015 to US\$148,842.1 million or around IDR 2,207 trillion in 2019.

Indonesian people have a perception that overseas fruit has more value than local fruit [2]. The appearance of imported fruit that is more attractive compared to the appearance of local fruit is one of the reasons consumers prefer imported fruit. In general, the attributes of imported fruit that become an attraction for consumers are sweetness to taste, attractive color, and low price [3]. Apple is one type of fruit that contains low saturated fat and zero cholesterol and has benefits in supporting health, including improving heart health, preventing asthma, cleaning the liver, reducing cholesterol, and helping the immunity of the human body [2]. In pandemic conditions, high awareness in society of the role of apples for health, especially in helping the body's immunity, can be a driver of increasing demand for apples.

The types of imported apples that enter the market in Indonesia are Fuji apples from China, or Washington apples from the United States, New Zealand apples, and Australian apples [2]. People's fear of the transmission of covid19 brings its perception for consumers in consuming fruit originating from China, considering China is the first country to emerge and the development of the covid19 virus $[4,5]$. This situation provides an opportunity for the government to encourage the consumption of local fruit products. Malang as a producer of local apples, also in the period before the pandemic covid19, experienced marketing conditions that are increasingly shifted with imported apples. In the 1990 s can still be seen apples become the icon of Malang and Batu. Imported fruit can be ensured only sold in supermarkets [6]. However, the current conditions are very different, where each small fruit stall and traditional market also sells a variety of imported apples. With the pandemic covid19, it is necessary to know the factors that affect the consumption preferences of local apples Malang and imported apples.

\section{Literature Review}

Preferences are part of the decision-making component of an individual. In total, the components are :p, attitudes, values, tendencies [7]. According to [8], preference is an expression of an assessor's emotional statement or reaction that leads to choosing the most preferred product. The occurrence of shifting consumption behavior is an indication of a shift in consumer perception of local fruit. Perception will lead consumers to build awareness of this product. Perception and awareness will shape consumers' attitudes in choosing which products to consume, be it local fruit or imported fruit. The product chosen is the preferred product by the consumer based on the consumer's preferences.

There are several studies related to consumer preferences, among others, consumer preferences for citrus fruits [9] which resulted in research that freshness, taste, and appearance are the most critical concerns of fresh oranges. Whereas [10] in his study found several factors that influence consumer preferences, namely the quality of oranges, social aspects, cognitive aspects, economic aspects, motivation, and continuous availability of oranges. Indicators of each of these factors are known citrus flavor parameters have the largest role to indicator the quality of oranges, the number of family members is the parameter with the largest role to the indicators of social aspects, the respondent's experience is the parameter with the largest role to the indicator of cognitive aspects, the parameter of the price of oranges has the largest role to the indicators of economic aspects, and parameters as a complement to daily needs are parameters with the largest role of the respondent's motivational indicators.

Similar research was also conducted by [11], which also examines the preference of citrus fruits, and the result is the attributes of local citrus fruits that consumers believe are freshness, shelf life, and vitamin content while the attributes of imported citrus fruits are 
freshness, color, number of seeds, shelf life, and vitamin content. The factors that affect the number of local citrus fruit purchases are household income and family members. For research on preferences for organic fruits and vegetables has been conducted by [12] [13], which results in that attributes that consumers consider when buying organic fruits and vegetables are benefits, flavors, visual attractiveness, and price. As for the research of preferences for local fruits and imports conducted by [14], produce attributes that become consumers' attraction are taste, price, color, usefulness, and freshness.

Research on the preferences of apples is conducted by [15] were the results of this study found that there has been a change in attitudes over several years where young people prefer local apples because they are more guaranteed food safety. While the research conducted by [3] produced that respondents in Surabaya and Malang had a positive attitude toward both local apples and imported apples. Overall the attributes of local apples have an advantage over the texture attributes of fruit meat. In contrast, imported apples have an advantage on the attributes of price, taste, size, color, skin condition, and promotion. For research on the preference of local apples is carried out by [16] and preference for fresh fruit from China [17]. The study also measured consumers' attitudes towards fruits based on evaluation or consumer attitudes towards some of the attributes of fruits and vegetables studied. Some researchers cite the consumer's attitude as a preference for fruits and vegetables studied.

Factors that influence consumer preferences are Socio-demographic factors such as age, education of health concerns, knowledge and awareness of eco-labels, environmental concern, price of organic food [18]. Similar research was also conducted by [19] where this study confirms that socio-economic such as income and education influence purchasing decision of organic food, also health consciousness, knowledge, subjective norms, price, and availability are essential factors of the actual purchasing decision respondents for organic food products. [20] also conduct research that obtains results that visual, flavor, and texture characteristics can also influence by culture, consumption frequency, and cultivar knowledge. Factors that become consumer preferences in buying imported apples are price, quality, promotion, nutrition, and customer's perception (color, product size, variety, container size, region of origin, mature season) [21]. Similar research was also conducted by (Widiyanto et al., 2016) the purpose of the study is to examine the competitiveness of local apples to imported apples reviewed from the attributes contained in local apples and imports and know the attitude of consumers to the attributes of apples and review the attributes that become the preferences of consumers of apples, especially in Surabaya and Malang. The result of the study was that respondents in Surabaya and Malang had a positive attitude toward both local apples and imported apples. Overall the attributes of local apples have an advantage on the texture attributes of fruit meat, while imported apples have an advantage on the attributes of price, taste, size, color, skin condition, and promotion.

Freshness, taste, and aroma are the most important attributes that consumers take into account when consuming fruits and vegetables [15]. As well as research conducted by [22] and [9] found that sweetness, shape, acidity, and taste were the most important factors affecting consumers. In addition to sensory attributes, trust attributes also play an essential role in consuming fruits and vegetables. Studies conducted in various countries have found that trust attributes, such as price, origin, production methods, and quality indicators, are essential in consideration of fruit purchases[23]; [15]. Consumers are willing to pay a premium price for domestic agricultural products because it has better quality and food safety standards [24].

Based on the above statement and the results of previous research, it can be interpreted that attitude is an expression of consumer feelings to express likes or dislikes to a product, and attitude can also describe consumer confidence in various attributes and benefits of the 
object. According to [25], there are three models of consumer attitude, namely: (1) Threecomponent model, (2) Fishbein Multiatribut attitude model, and(3) Ideal number attitude model. Based on these three models, the most popular use by researchers is to use the Multi-Attribute Attitude Model from Fishbein. Fishbein's Multiatribut model will in principle, calculate Ao (Attitude toward the object), a person's attitude towards an object, which is recognized through the attributes attached to the object [25]. The introduction of an object through the way of seeing, fingering, trying, and using the object for a long time, then a consumer will have a certain attitude towards the object used or used. Generally, before the consumer consumes an object, they first expect the object. So that as soon as they see, try and use it, a consumer can assess whether the object in question has been following its expectations.

Several studies have used the multi-attribute model of Fishbein as an analysis tool in their research, namely: research on consumer behavior in the purchase of wine [26]. The study was conducted to compare the impact of wine tasting overtime at home. [27] also, use a multi-attribute model of Fishbein to analyze the consumption preferences of strawberries. Analysis of consumer attitudes is measured using the Fishbein Multiatribut Model, which describes that consumer attitude towards a product or brand, determined by two things, namely trust in the attributes owned by the product or brand (bi) and evaluation of the importance of attributes of the product (i.e.). Based on previous research data that uses the multiattribute Fishbein model as a tool to analyze consumer attitudes towards a product, then in the assessment of people's preference towards the consumption of local apples Malang and imported apples will be conducted with a multiattribute model to analyze consumer attitudes towards local apples Malang and imported apples. In general, after knowing the attitude of consumers towards local apples Malang and imported apples, prmben factors form preferences will be analyzed using the Principal Component Analysis (PCA) method. Principal Component Analysis is a technique commonly used to simplify data by linearly transforming data so that a new coordinate system with maximum variance is formed. The purpose of the PCA is (1) to extract the most crucial information from the data table; (2) to compress the size of the data set by storing only this vital information; (3) to simplify the description of the data set; (4) Analysis of observation structure and its variables [28].

Some other studies that use the Principal Component Analysis (PCA) method are [29], which researched the behavior of dietary patterns. [30] also used the PCA method to analyze fruit production and consumption in Western Kenya. The PCA method was also used in research [16] which examines consumers' preferences for organic foods in everyday life. [31] also used the PCA method to examine the influence of sensory quality on the apple preferences of elementary school children. In this study, sensory features of four varieties of fresh apples were performed on children aged 6-10 years in the Middle East region of Italy (Abruzzo). The sensory properties examined were visually appealing, aromatic, sour, sweet, hard, and crunchy. Statistical analysis is done by analyzing the main components that underline the differences and similarities between the examined fruit and the most responsive variables. So the results were obtained that different varieties influence each other for the perception of some sensory characteristics.

\section{Research Methods}

\subsection{Population}

The population used in this study is consumers who have purchased or consumed local Malang apples and or imported apples during the pandemic (March-July 2020). A 
purposive sample determines the sampling method. The determination of samples is done random sampling through questionnaires either offline or online or google form. The number of samples from this study was 110 respondents.

\subsection{Data Analysis Method}

The research method of local apple consumption Malang and imported apples during the pandemic covid-19 is quantitative research wherein the research uses data in the form of numbers as a tool to analyze it using the approach of survey methods. The basic method used in this study is a descriptive method to describe the current phenomena with the selection of research variables relevant to the issue. The research was conducted by analyzing consumer preferences with primary data obtained through questionnaires on respondents. Questionnaires are created on a Likert scale (1-5) to make it easier to determine preference values. To analyze the factors that shape consumer preferences of local apples Malang and imported apples during the Covid-19 pandemic used SPSS application version 25. The method used is the Principal Component Analysis (PCA) method. Principal Component Analysis is a technique commonly used to simplify data by transforming data linearly to form a new coordinate system with maximum variance [28]. PCA analysis can significantly reduce the dimensions of data without significantly reducing the characteristics of that data [32]. Usually, decisions in the Principal Component Analysis (PCA) method are taken by the predefined variant levels $(90,95,99$, or $99.9 \%)$ or based on experimental errors [33]. Based on [34] PCA analyzed is:

1. Standardization the data

$$
z=\frac{\text { value-mean }}{\text { standard deviation }}
$$

2. Covariance Matrix Computation

The covariance matrix is a $p \times p$ symmetric matrix (where $p$ is the number of dimensions) that has as entries the covariance associated with all possible pairs of the initial variables.

3. Compute Eigenvectors and Eigenvalues of Covariance Matrix

Eigenvectors and eigenvalues are the linear algebra concepts that compute from the covariance matrix to determine the principal components of the data.

\section{Results and Discussion}

\subsection{Consumer Characteristics}

\subsubsection{Gender}

It is known that more than half the number of consumers $(75 \%)$ female gender. In comparison, the remaining $25 \%$ are male. The distribution of consumers by gender can be seen in Table 1.

Table 1. Consumer Distribution By Gender

\begin{tabular}{|c|c|c|}
\hline Gender & Number (n) & Percentage (\%) \\
\hline Men & 27 & 25 \\
\hline Female & 83 & 75 \\
\hline Total & 110 & 100 \\
\hline
\end{tabular}




\subsubsection{Age}

The distribution of characteristics based on the age of the consumer can be seen in Table 2. In the table, the results of data calculation can be seen based on age factor that the largest percentage of consumers' age is $21-30$ years of age by $34 \%$ with the number of 37 people. This data shows that at the age of 21-30 years is a potential group in making decisions on the purchase of apples. This is because at that age, including productive age and aware of the importance of consuming fruits for their body [12].

Table 2. Consumer Characteristics By Age

\begin{tabular}{|c|c|c|}
\hline Age (Year) & Number (n) & Percentage (\%) \\
\hline $11 \mathrm{~s} / \mathrm{d} 20$ & 6 & 5 \\
\hline $21 \mathrm{~s} / \mathrm{d} 30$ & 37 & 34 \\
\hline $31 \mathrm{~s} / \mathrm{d} 40$ & 17 & 16 \\
\hline $41 \mathrm{~s} / \mathrm{d} 50$ & 30 & 27 \\
\hline $51 \mathrm{~s} / \mathrm{d} 60$ & 20 & 18 \\
\hline Total & 110 & 100 \\
\hline
\end{tabular}

\subsubsection{Job Type}

Jobs type owned by consumers is also one factor that influences a consumer's purchasing decision (Rahayu et al., 2012). This is because the type of work a person does will affect his socio-economic status.

Table 3. Consumer Charateristics By Job Type

\begin{tabular}{|c|c|c|}
\hline Profession & Number (n) & Percentage (\%) \\
\hline Gov. Officer & 24 & 22 \\
\hline Private & 18 & 16 \\
\hline Army/ Police & 3 & 3 \\
\hline House wife & 15 & 14 \\
\hline Student & 17 & 15 \\
\hline Entrepreneur & 22 & 20 \\
\hline At.al & 11 & 10 \\
\hline Total & 110 & 100 \\
\hline
\end{tabular}

Based on Table 3 above, most of the respondents are the group of Civil Servants by $22 \%$, while the Entrepreneurial group is also not much different from the group of Civil Servants that is $20 \%$. But it cannot be concluded that the civil servants or entrepreneurs are potential consumers of local apples and imports because all groups realize the importance of consuming fruits, especially during the pandemic.

\subsubsection{Education}

One's education will usually be associated with a level of knowledge and will affect one's attitudes and behaviors [19]. This is in line with the results of this study that the higher the level of education of a person, the broader one's insight and knowledge, so knowledge of the fulfillment of the needs of fruit consumption will also be more selective for the completion of nutrition. Especially during a pandemic like this, someone who knows the importance of nutritional fulfillment will consume more fruits to increase the body's level of immunity or immunity. Here is the distribution of characteristics based on consumer education can be seen in Table 4 . 
Table 4. Consumer Characteristic By Education

\begin{tabular}{|c|c|c|}
\hline Education & Number $(\mathrm{n})$ & Percentage (\%) \\
\hline Elementaary School & 8 & 7 \\
\hline Junior High School & 12 & 11 \\
\hline Senior High School & 37 & 34 \\
\hline College & 53 & 48 \\
\hline Total & 110 & 100 \\
\hline
\end{tabular}

\subsubsection{Income and Expenditure}

The income level measured in this study is the total income in the consumer's monthly household. The higher a person's income, the greater the chance of buying an item or service [19]. From these results, most respondents have a range of income between IDR $2,500,000$ - IDR 5,000,000, with the number of consumers as much as $35 \%$. The income level measured in this study is the total income in the consumer's monthly household. The higher a person's income, the more diverse food choices are than low-income comments because low-income consumers have a higher awareness of the price and value of products that influence their purchasing decisions [35]. From these results, most respondents have a range of income between IDR 2,500,000 - IDR 5,000,000, with the number of consumers as much as $35 \%$.

Table 5. Consumer Characteristic By Income

\begin{tabular}{|c|c|c|}
\hline Income (IDR) & Number (n) & Percentage (\%) \\
\hline$<1,000,000$ & 25 & 23 \\
\hline $1,000,001-2,500,000$ & 28 & 25 \\
\hline $2,500,001-5,000,000$ & 38 & 35 \\
\hline$>5,000,000$ & 19 & 17 \\
\hline Total & 110 & 100 \\
\hline
\end{tabular}

Revenue will also be directly proportional to expenses. The greater the income, the greater the expenditure spent by a person [36]. The expenditure measurements conducted in this study are also household expenditures per month. According to [37], Engel's law states that households with low wages or incomes will spend most of their income to buy necessities. In contrast, high-income households will spend only a fraction of the total expenditure on necessities. Based on income and expenditure data, it can be concluded that most consumers have a considerable opportunity to buy apples, because in the revenue data most consumers have income that includes high intervals as well as spending data including intervals that tend to be high above 1 million. Here is the data on consumer spending in each month.

Table 6. Consumer Characteristic By Expenditure

\begin{tabular}{|c|c|c|}
\hline Expenditure (IDR ) & Number (n) & Percentage (\%) \\
\hline$<1,000,000$ & 22 & 20 \\
\hline $1,000,001-2,500,000$ & 41 & 37 \\
\hline $2,500,001-5,000,000$ & 36 & 33 \\
\hline$>5,000,000$ & 11 & 10 \\
\hline Total & 110 & 100 \\
\hline
\end{tabular}

\subsubsection{Number of Family Members}

The number of family members can also affect the level of consumption in a household. The more the number of family members, the higher the level of consumption in the 
household. Families consume various types of food in one food consumption compared to individual consumption [38]. It is included the entire number of household family members who live and eat from one kitchen with a group of residents. The group in question eats from one kitchen when the caretaker of daily needs is managed together. So, included in the number of family members are those who have not been able to meet their daily needs because they have not worked (in non-productive age) so need the help of others (in this case, parents). Based on the study results that can be seen in Table 7, 61 consumers have family members as many as 4 to 5 people (56\%). Thus, it can be concluded that the level of consumption of respondents involved in this study is high because the number of family members owned by consumers is quite large. Here are consumer characteristics data based on the number of family members.

Table 7. Consumer Characteristic By Number of Family Members

\begin{tabular}{|c|c|c|}
\hline The Number of Family Members (orang) & Number (n) & Percentage (\%) \\
\hline$<3$ & 40 & 36 \\
\hline $4 \mathrm{~s} / \mathrm{d} 5$ & 61 & 56 \\
\hline$>5$ & 9 & 8 \\
\hline Total & 110 & 100 \\
\hline
\end{tabular}

\subsection{Apple Consumption}

In the process of consuming apples both locally and imported, there are several considerations carried out, including the following:

\subsubsection{Price and Buying Quantity of Apples}

The price of a product may affect the number of purchases of such products. Similarly, the apples studied, known in various price ranges in the market, are strongly influenced by the quality of the fruit. Based on the research that has been done, local apples Malang has a lower price than imported apples. Logically, consumers would prefer to buy local apples compared to imported apples. But often found in the market of apples both local and imported, traders give promo prices Table 8 .

Table 8. Price Range Accepted By Consumer

\begin{tabular}{|c|c|c|}
\hline Price (IDR ) & $\begin{array}{c}\text { Local Apple Malang } \\
(\%)\end{array}$ & $\begin{array}{c}\text { Import Apple } \\
(\%)\end{array}$ \\
\hline $10,000-20,000$ & 68 & 42 \\
\hline $21,000-30,000$ & 20 & 21 \\
\hline$>30,000$ & 12 & 37 \\
\hline Total & 100 & 100 \\
\hline
\end{tabular}

Table 9. Number Of Purchases of Each in Apples

\begin{tabular}{|c|c|c|}
\hline Number of Purchase (kgs) & $\begin{array}{c}\text { Local Apples Malang } \\
(\%)\end{array}$ & $\begin{array}{c}\text { Imported Apples } \\
(\%)\end{array}$ \\
\hline $1-2 \mathrm{~kg}$ & 78 & 66 \\
\hline $3-5 \mathrm{~kg}$ & 10 & 19 \\
\hline$>5 \mathrm{~kg}$ & 12 & 15 \\
\hline Total & 100 & 100 \\
\hline
\end{tabular}

Based on the price in the market, it is known that $68 \%$ of local apple consumers expressed the ability to receive prices in the range of IDR 10,000-20,000. But on imported apples, although they also often experienced promo prices, $37 \%$ of consumers stated able to 
pay prices above IDR 30,000 . The ability to pay the price of apples also greatly affects the number of purchases of apples made by consumers during the Covid19 pandemic. From Table 9, it is known that more than 65 percent of ordinary consumers buy apples both locally and imported as much as $1-2 \mathrm{~kg}$.

\subsubsection{Passion in Consuming Apples}

The penchant for consuming apples greatly affects the level of consumption of apples because if a person has loved something, then he relatively often consumes something that is favoured. Similarly, if a person has loved apples, the person will tend to consume apples often. The results of this study are known that 25 percent of consumers expressed their fondness for both types of apples (local and imported). But 28 percent of consumers prefer imported apples from local apples. And interestingly there is 20 percent of respondents say they do not like apples but still buy apples because it is an order of family members.

Table 10. Apples Consumer by Its Passion

\begin{tabular}{|c|c|c|}
\hline Information & Number (n) & Percentage (\%) \\
\hline Like Apples & 30 & 27 \\
\hline Like Imported Apples & 31 & 28 \\
\hline Like Both of type & 27 & 25 \\
\hline Nor like Both & 22 & 20 \\
\hline Total & 110 & 100 \\
\hline
\end{tabular}

\subsubsection{The Location to Buying Apples}

Where to buy apples is also an important indicator because it can affect the purchase price of apples the more modern the place to buy fruit, the more expensive the seller offers. But the quality offered is also different [39]. Here's the respondent data based on where to buy apples, both local Malang and imported apples.

Table 11. The Location to Buying Local and Imported Apples

\begin{tabular}{|c|c|c|c|c|}
\hline \multirow{2}{*}{ Location to Buy } & \multicolumn{2}{|c|}{ Local Apples } & \multicolumn{2}{c|}{ Imported Apples } \\
\cline { 2 - 5 } & Number (n) & Percentage (\%) & Number (n) & Percentage (\%) \\
\hline Local Merchant & 83 & 75 & 75 & 68 \\
\hline Tradisional Market & 20 & 18 & 13 & 12 \\
\hline Modern Market & 6 & 6 & 21 & 19 \\
\hline Online Market & 1 & 1 & 1 & 1 \\
\hline Total & 110 & 100 & 110 & 100 \\
\hline
\end{tabular}

Percentage of respondents who choose to shop for apples locally imported largest at good local traders who are across the road so that it is easy to reach some local traders usually go around offering fruits selling. In addition to local traders, $19 \%$ of respondents of imported apples often buy the apple fruit in the modern market and its diverse price and many options. This is similar to research [39] that fruit consumers consider location factors an essential factor that consumers consider when making fruit purchases.

\subsection{Apples Fruit Preference}

Data on apple preferences taken from respondents were approached from various attributes of local apples Malang, and imported apples are as follows: (1) Size, (2) Color, (3) Packaging, (4) Label (5) Texture (6) Freshness, (7) Organic, (8) Benefits, (9) Ease in obtaining it, (10) Cleanliness, and (11) Taste. 
Based on apple's attributes, a Principal Component Analysis (PCA) test is conducted using SPSS application version 25. PCA is a research method that aims to identify, group, and reduce factors that are the dimensions of a variable [40]. The results of the PCA test conducted then form a new factor that can be said to be the forming factor of the preference of apples. The results of the PCA can be seen in Table 12 .

Table 12. The Result of Factors Test Apples Local \& Imported

\begin{tabular}{|c|c|c|c|c|c|c|}
\hline & \multicolumn{3}{|c|}{ Malang Local Apples } & \multicolumn{3}{c|}{ Imported Apples } \\
\cline { 2 - 7 } & Factor 1 & Factor 2 & Factor 3 & Factor 1 & Factor 2 & Factor 3 \\
\hline Size & 0.593 & -0.135 & 0.188 & 0.445 & 0.160 & -0.060 \\
\hline Color & 0.627 & -0.380 & -0.479 & 0.553 & 0.366 & -0.554 \\
\hline Packaging & 0.699 & -0.410 & -0.047 & 0.539 & 0.652 & -0.192 \\
\hline Label & 0.645 & -0.509 & -0.041 & 0.547 & 0.623 & 0.098 \\
\hline Texture & 0.629 & -0.034 & -0.119 & 0.732 & -0.184 & -0.261 \\
\hline Freshness & 0.549 & 0.640 & -0.242 & 0.803 & -0.435 & 0.004 \\
\hline Organic & 0.476 & 0.057 & 0.644 & 0.456 & 0.188 & 0.603 \\
\hline Benefits & 0.562 & 0.258 & 0.617 & 0.701 & -0.224 & 0.486 \\
\hline Ease in Obtaining & 0.484 & 0.001 & -0.052 & 0.548 & 0.215 & 0.314 \\
\hline Cleanliness & 0.382 & 0.664 & -0.269 & 0.592 & -0.423 & -0.383 \\
\hline Taste/Flavour & 0.441 & 0.400 & -0.160 & 0.798 & -0.347 & 0.013 \\
\hline
\end{tabular}

The factors formed result from the grouping of the component matrix value obtained after the PCA test. Factor grouping determines each of the initial factors to fit into the newly formed factors [41]. Based on the results of the component matrix above, there are several attributes that shape the first, second, and third factors, as in Table 13.

Table 13. Classification of Attributes of Local Apples and Imported Consumer Preference

\begin{tabular}{|c|l|l|}
\hline Factor to- & \multicolumn{1}{|c|}{ Local Apples } & \multicolumn{1}{c|}{ Imported Apples } \\
\hline 1 & $\begin{array}{l}\text { Performance: Size, Colour, packaging, } \\
\text { Label, Texture, Ease in Obtaining and } \\
\text { Taste }\end{array}$ & $\begin{array}{l}\text { Performance: Size, Colour, Freshness, } \\
\text { Benefits, Ease in Obtaining, Cleanliness } \\
\text { \& Taste }\end{array}$ \\
\hline 2 & Appearance : Freshness \& Cleanliness & Packaging : Packaging \& Label \\
\hline 3 & Green Product : Organic \& Benefits & Green Product : Organic \\
\hline
\end{tabular}

After all, attributes are entered on new factors formed from the results of the PCA test, then the naming of the factors formed. Grouping factors and naming new factors (labeling) is the last step in conducting data analysis using PCA [41]. The new factor formed is the forming factor of the preference of local and imported apple consumption. In Table 13, there are three factors formed in the preference of local apples Malang and imported apples.

Based on the table above, it is obtained that the forming factors of the preference of local apples and imported apples are likely to be the same, it's just that the attributes of each factor are different. Factor 1 in local and imported apples is called performance, factor 2 in local apples is called appearance, while in imported apples are called packaging. And factor 3 both in local and imported apples is called Green Product. It shows that performance, appearance, packaging, and green product are important as a plus of apples both local apples Malang and imported apples during this pandemic. In addition to being value-added, these factors can also be used to attract consumers to keep choosing to consume local apples Malang and imported apples.

\subsection{Purchase Decision and The Effect of Apples Purchase Decision}

The data obtained in this study explained that most respondents plan to purchase apples in advance in deciding to consume apples both locally and imported. In other words, most of 
the decisions on buying local and imported apples are self-will and influenced by the family.

Table 14. Reference Factors in Influencing Apple Purchase Decisions

\begin{tabular}{|l|c|c|}
\hline The Reference Factors & $\begin{array}{c}\text { Malang Local Apples } \\
(\%)\end{array}$ & $\begin{array}{c}\text { Imported Apples } \\
(\%)\end{array}$ \\
\hline Will Own & 63.64 & 50.91 \\
\hline Family & 23.64 & 26.36 \\
\hline Sales & 3.64 & 8.18 \\
Friends & 9.09 & 14.55 \\
\hline Total & 100 & 100 \\
\hline
\end{tabular}

The results of this study in Table 14 show that families also influence more than 20 percent of apple purchase decisions. Family or closest people who usually participate in the order are parents, children, wives/husbands, or other relatives and friends. The reasons they order are also diverse there are used for diet, herbal ingredients, daily consumption up to meet the needs of 4 healthy five perfect. In Table 15, it is known that mother and son orders dominate the decision to buy apples both locally and imported

Table 15. The Family Members Influence on Purchase Decision

\begin{tabular}{|l|c|c|}
\hline Order from & Malang Local Apples (\%) & Imported Apples (\%) \\
\hline Husband & 11 & 12 \\
\hline Wife & 14 & 12 \\
\hline Father & 15 & 14 \\
\hline Mother & 26 & 26 \\
\hline Children & 29 & 32 \\
\hline At.al & 5 & 4 \\
\hline Total & 100 & 100 \\
\hline
\end{tabular}

\section{Conclusions}

Based on the results of the discussion in the research, it can be concluded that:

1. The average price for apples per kilo for both local and imported is in the range of $10,000-20,000$, with the average amount of one purchase for both types of apples is about 1-2 kg. Respondents who liked apples imported more than local apples. The place of purchase of local apples is dominated by local traders whose access is accessible on the side of the road and traditional markets, while imported apples, in addition to local traders, are also on the modern market.

2. There are three factors that affect consumer preferences towards local apples: performance, appearance, and green, while in imported apples, the packaging is also green.

3. Local and imported apple purchases are dominated by self-will/awareness as well as family. While in the family known mother and child determine the purchase of fruit for the family to consume.

\section{Reference}

1. T. Eftimov, G. Popovski, M. Petković, B. K. Seljak, and D. Kocev, Trends Food Sci. Technol. 104, 268 (2020).

2. J. N. Rahayu, Elys Fauziyah, and Aminah HM Ariyani, Agriekonomika 1, 52 (2012).

3. N. A. Widiyanto, A. K. Adhi, and H. K. Daryanto, 9, 136 (2016).

4. M. M. C. Otálora, Parq. Los Afectos. Jóvenes Que Cuentan 2, 124 (2020). 
5. M. R. Hutauruk, 2, 1 (2020).

6. A. S. Slamet and A. Nakayasu, Acta Hortic. 1179, 1 (2017).

7. S. Rochaeni, Agribus. J. 7, 91 (2013).

8. M. Mora, E. Urdaneta, and C. Chaya, Food Qual. Prefer. 66, 19 (2018).

9. Z. Gao, L. O. House, F. G. Gmitter, M. F. Valim, A. Plotto, and E. A. Baldwin, Int. Food Agribus. Manag. Rev. 14, 23 (2011).

10. M. SAVITRI, R. YUSUF, and I. SUARDI, E-Journal Agribisnis Dan Agrowisata (Journal Agribus. Agritourism) 5, 439 (2016).

11. M. J. Rajagukguk, W. D. Sayekti, and S. Situmorang, Jiia 1, 326 (2013).

12. R. Moser, R. Raffaelli, and D. Thilmany-McFadden, Int. Food Agribus. Manag. Rev. 14, 121 (2011).

13. T. Vukasovič, Http://Dx.Doi.Org/10.1080/08974438.2015.1006974 28, 59 (2016).

14. D. Yosini, Agron. Ser. Sci. Res. 54, 32 (2011).

15. U. Moor, A. Moor, P. Põldma, and L. Heinmaa, Agric. Food Sci. 23, 135 (2014).

16. T. Christensen, S. Denver, S. B. Olsen, T. Christensen, S. Denver, and S. Bøye, 4438, (2019).

17. E. peng WANG, Z. Gao, and Y. Heng, J. Integr. Agric. 17, 1463 (2018).

18. N. Dangi, S. K. Gupta, and S. A. Narula, Manag. Environ. Qual. An Int. J. 31, 1515 (2020).

19. A. Singh and P. Verma, J. Clean. Prod. 167, 473 (2017).

20. M. V. Galmarini, R. Symoneaux, S. Chollet, and M. C. Zamora, Appetite 62, 27 (2013).

21. S. Jiajia and H. Xuexi, Br. J. Econ. Manag. Trade 5, 135 (2015).

22. F. P. van den Heuvel, P. W. de Langen, K. H. van Donselaar, and J. C. Fransoo, Beta Work. Pap. 354, 26p. (2011).

23. B. L. Campbell, S. Mhlanga, and I. Lesschaeve, Agric. Resour. Econ. Rev. 42, 518 (2013).

24. S. Jin and J. Zhou, Food Control 22, 204 (2011).

25. W. Widiyanti, 19, 107 (2019).

26. S. Tempere, S. Pérès, A. F. Espinoza, P. Darriet, E. Giraud-Héraud, and A. Pons, Food Qual. Prefer. 73, 110 (2019).

27. K. Wendin, P. A. Egan, V. Olsson, S. Forsberg, A. Nilsson, and J. A. Stenberg, Int. J. Gastron. Food Sci. 16, 100151 (2019).

28. S. Mishra, U. Sarkar, S. Taraphder, S. Datta, D. Swain, R. Saikhom, S. Panda, and M. Laishram, Int. J. Livest. Res. 7, 1 (2017).

29. M. G. Thorpe, C. M. Milte, D. Crawford, and S. A. McNaughton, Int. J. Behav. Nutr. Phys. Act. 13, 1 (2016).

30. G. B. Keding, K. Kehlenbeck, G. Kennedy, and S. Mcmullin, (2017).

31. B. Lanza, N. Sabatini, and M. Bacceli, Https://Doi.Org/10.1177/1082013217719338 23, 729 (2017).

32. A. Tefas and I. Pitas, Intell. Syst. 14, 641 (2017).

33. D. Granato, J. S. Santos, G. B. Escher, B. L. Ferreira, and R. M. Maggio, Trends Food Sci. Technol. 1 (2017).

34. Z. Jaadi, (2021). 
35. I. H. Steenhuis, W. E. Waterlander, and A. de Mul, Public Health Nutr. 14, 2220 (2011).

36. A. Ruwani, M. Simanjuntak, and P. Foods, 7, 48 (2014).

37. W. Nicholson and C. (Christopher M. Snyder, Microeconomic Theory Basic Principles and Extensions, 12th ed. (Cengage Learning, Boston, 2017).

38. E. M. Welsh, S. A. French, and M. Wall, J. Nutr. Educ. Behav. 43, 229 (2011).

39. I. Effendi, M. Najib, and K. Brandoko, J. Consum. Sci. 4, 61 (2019).

40. S. G. Natyari and M. Pradana, Int. J. Emerg. Technol. Eng. Res. 10, 7 (2016).

41. I. T. Jollife and J. Cadima, Philos. Trans. R. Soc. A Math. Phys. Eng. Sci. 374, (2016). 